\title{
Ortaokul Fen Bilimleri Ders Kitaplarında Grafik Düzenleyici Kullanımının İncelenmesi*
}

\section{Examining of Graphic Organizers' Usage in Secondary School Science Textbooks}

\section{Canan NAKİBOĞLU*}

\author{
Şafak YILDIRIM ${ }^{* * *}$
}

\begin{abstract}
Received: 09 May 2018
Research Article

Accepted: 07 November 2018

ABSTRACT: Graphic organizers are learning and teaching materials that present the relationship between concepts in a visual design. The inclusion of graphical organizers in textbooks helps the students to learn the theoretical knowledge presented in the book in a meaningful way, while helping to connect the concepts of the subject and previous topics. For this reason, it was aimed to determine the degree and purpose of graphic organizers placed in secondary school science textbooks. The textbooks of 5th, 6th, 7th and 8th grade science courses which are being studied in the academic year of 2017-2018 were analyzed and the results were compared in this study. At the end of the study, it was concluded that 46 graphic organizers, 17 in the 5th grade science textbook, 8 in the 6 th grade science textbook, 12 in the 7th grade science textbook and 8 in the 8 th grade science textbook were used in the secondary school science books examined. At the end of the study, some recommendations for including graphic organizers in secondary school science lessons were presented.
\end{abstract}

Keywords: graphic organizer, secondary school science textbooks, science teaching.

ÖZ: Grafik düzenleyiciler, kavramlar arasındaki ilişkileri görsel şekilde sunan öğrenme ve öğretme materyalleridir. Grafik düzenleyicilere ders kitaplarında yer verilmesi bir yandan öğrencinin kitapta sunulan teorik bilgiyi anlamlı bir şekilde öğrenmesine yardımcı olurken diğer yandan konunun kavramları ve önceki konular arasında bağlantı kurulmasına yardım eder. Bu nedene, çalışmada, Ortaokul Fen Bilimleri ders kitaplarında grafik düzenleyicilere ne derece ve hangi amaçla yer verildiğini ve hangi tür grafik düzenleyiciler olduğunun belirlenmesi amaçlamıştır. 20172018 Eğitim-Öğretim yılında okutulmakta olan, 5., 6., 7., ve 8. sınıf Fen Bilimleri ders kitaplanı analiz edilerek, sonuçlar kıyaslanmıştır. Çalışma sonunda incelenen Ortaokul Fen Bilimleri kitabından, 5. sınıf kitabında 17 adet, 6. Sınıf kitabında 8 adet, 7. Sinıf kitabında 12 adet ve 8 . sınıf kitabında 8 adet olmak üzere toplam 46 adet grafik düzenleyicinin yer aldığı sonucuna ulaşılmıştır. Çalışmanın son kısmında, Ortaokul Fen Bilimleri derslerinde grafik düzenleyicilerin kullanılması ile ilgili öneriler sunulmuştur.

Anahtar kelimeler: grafik düzenleyici, ortaokul fen bilimleri ders kitapları, fen bilgisi öğretimi.

\footnotetext{
* This study was presented at UBEK-ICSE 2018, but not completely published.

** Corresponding Author: Prof. Dr., Balıkesir University, Balıkesir, Turkey, canan@ balikesir.edu.tr

**** MSc Student, Balıkesir University, Balıkesir, Turkey, safakimya@ gmail.com
}

Citation Information

Nakiboğlu, C. \& Yıldırım, Ş. (2018). Ortaokul fen bilimleri ders kitaplarında grafik düzenleyici kullanımının incelenmesi. Kuramsal Eğitimbilim Dergisi [Journal of Theoretical Educational Science], UBEK-2018, 1-23. 


\section{Giriș}

Yaşadığımız dünyayı anlamak, etrafımızda gerçekleşen olayları açıklamak ve yaşantımızı kolaylaştıracak teknolojiyi üretebilmek için fen bilimleri bilgisine ihtiyaç duyarız. Bu nedenle ülkeler çocukların çok küçük yaşlardan itibaren fen bilimlerini anlamlı bir şekilde öğrenmesi için büyük gayretler sarf etmekte ve programlarında yaptıkları düzenlemelerle fenin daha iyi anlaşılmasına uğraşmaktadırlar. Diğer taraftan yapılan birçok çalışma, fen öğrenimi ile ilgili her yaş grubundaki öğrencilerin sorunlar yaşadığını ve zaman zaman anlamlı öğrenmenin gerçekleşemediğini göstermiştir (Nakiboğlu, 2003; Taber, Tsaparlis, \& Nakiboğlu, 2012; Tsaparlis, 1997).

Anlamlı öğrenmede yeni öğrenilen kavramlar, öğrenenin zihninde önceki derslerde öğrenilmiş kavramlarla birbirine hiyerarşik bir şekilde bağlanması gerekir (Nakiboğlu \& Çamurcu, 2014). Ausubel (1960), öğrencilerin öğrenme sürecini kolaylaştırmada yeni bilgi ile daha önceden kazanılan bilgi arasında mantıklı bir düzenlemenin sağlanmasında ön düzenleyici kullanımının önemli olduğunu ifade etmiştir. Dersin başlangıcında, öğrencilerin konu ilgili önemli kavramların ilişkilendirilmesini sağlamak amacıyla kullanılan ön düzenleyiciler, kavramların birbiri ile olan ilişkisini göstererek öğrencilerin zihinlerinde bir örüntü oluşmasını sağlar. Yazılı veya sözlü şekilde de olabilen ön düzenleyiciler aynı zamanda kavramlar arası ilişkilerin görsel bir formatta sunulması şeklinde de hazırlanabilirler. Bu tür öndüzenleyiciler aynı zamanda dersin girişinde kullanılabilecek birer grafik düzenleyici olarak dikkate alınabilir (Nakiboğlu \& Kaşmer, 2017).

Dersin girişinde kullanılan ön düzenleyicilerden farklı olarak dersin her aşamasında ve farklı amaçlar için kullanılabilen grafik düzenleyiciler öğrenme sürecinde konunun kavramları arasındaki ilişkileri gösteren görsel ve şekilsel araçlar olarak tanımlanır (Ellis, 2004; Strangman, Vue, Hall \& Meyer, 2003; Hudson, Lignugaris-Kraft, \& Miller, 1993; Nakiboğlu \& Çamurcu, 2014). Grafik düzenleyiciler, konunun farklı bileşenleri arasındaki benzerlikler, farklılıklar ve sıralamalar gibi bağlantıları ve ilişkileri görsel olarak sunması ile öğrencilerin düşüncelerini görünür yapabilmelerine ve karmaşık içerikleri anlamalarına yardımcı olan araçlardır (Amin, 2004). Dye (2002), grafik düzenleyici temellerinin Şema Teorisine dayandığını ve Şema Teorisine göre yeni bilgilerin önceden var olan bilgiye bağlı olması gerektiğini ifade etmiştir. Öğretmenin görevi, öğrencinin kavramla ilgili ön bilgiye sahip olduğundan emin olmak ve öğrencinin önceden var olan bilgisi ile öğretilen yeni kavram arasında gerekli bağlantıları yapmasına yardım edecek bir araç sağlamaktır.

Amin (2004), öğrencilerin çoğunun ve bazı öğretmenlerin, görsel öğrenenler olduğunu ve bu nedenle "bir resmin bin kelimeye değdiğini" belirterek, fikirleri, olguları ve kavramları grafiksel olarak organize etmenin bazı yollarının etkili öğrenci öğrenimini kolaylaştıracağını dile getirmiştir. Ayrıca çok sayıda eğitim ve bilişsel psikoloji araştırmacısının, grafiksel materyallerin öğrenciler tarafından oluşturulmasının, öğrencilerin konu içeriğini anlamalarını arttırabileceğini gösterdiğini ifade etmiştir. Grafik düzenleyicilerin, öğretilen konu ilgili kavramların birbiri ile olan ilişkisini ve mantıksal bağlantılarını göstermede, öğretim amaçlarının şekillenmesinde, öğrenilen materyalin gözden geçirilmesinde, dersin değerlendirilmesinde ve yeni bilgi ile eski bilginin ilişkilendirilmesinde kullanılması ile öğrenme sürecine katkı sağladığ 1 
araştırmacılarca ifade edilmiştir (Dönmez, Yazıc1, \& Sabanc1, 2007; Nakiboğlu \& Kaşmer, 2017).

Ortaokul kademesindeki öğrenciler yaşları gereği henüz soyut düşünme basamağına geçmemiş olmaları nedeniyle, fen bilimlerinde yer alan bazı soyut kavramları anlamakta zorlanmaktadırlar. Bunun yanı sıra bu düzeydeki öğrenciler arasında fennin kendi doğasından kaynaklanan bazı öğrenme güçlükleri de söz konusudur. $\mathrm{Bu}$ nedenle bu öğrencilerin derslerinde mümkün olduğunca karmaşık ve soyut konuların onların anlayacağı şekilde sadeleştirilmesi ve görsel hale getirilmesi önemlidir. Özellikle ortaokul seviyesinde öğretilen bazı konuların lise yıllarındaki kimya, fizik ve biyoloji dersleri için temel oluşturduğu düşünüldüğünde, bu yıllarda tam yapılandırılamayan bilgiler veya yanlış kavramalar ilerideki yıllarda yeni konuların anlamlı öğrenilmesine de engel olabilecektir. O nedenle ortaokul düzeyinde, fen konularının öğrenciler tarafından anlamlı şekilde yapılandırılması önemlidir.

Günümüzde derslerde farklı materyaller ve özellikle öğretim teknolojisi kullanımının çok fazla artmasına rağmen ders kitapları, hala öğretme ve öğrenme faaliyetlerinde önemli rollerini korumaktadırlar. Teknoloji ile birlikte ders kitapları sanal ortama taşınsa da ders kitapları, bilginin korunması ve iletilmesinde en önemli ders materyalleri olmayı sürdürmektedir (Morgil \& Y1lmaz, 1999). Bu nedenle özellikle yaşları daha küçük olan ortaokul öğrencilerinin kitaplarının görsel olarak da onlara hitap etmesi ve öğrenmelerine katkı sağlaması son derece önemlidir. Bu duruma bazı araştırmacılarca da dikkat çekilmiştir. Strangman ve diğerleri (2003) çalışmalarında, sorunlu ve öğrenci için karmaşık gelen konu ve kavramların öğretiminde grafik düzenleyici kullanımının öğrenmeye yardımcı olduğunu ifade etmişlerdir. Kulm ve diğerleri (1999), ders kitaplarının içeriğgi organize etmeleri ile öğrenciler için öğrenmeyi daha ilgi çekici hale getirmeleri sayesinde sadece bir dersin amacının ve planının ortaya konulmasında değil aynı zamanda sınıf içi etkinliklere de yardımcı olmada önemli bir role sahip olduklarını belirtilmişlerdir (akt: Köseoğlu ve diğerleri, 2003). Grafik düzenleyici kullanımı öğrencilerin hem konunun kavramlarını hem de konunun bütününü daha kolay hatırlayabilmesine ve konunun parçaları arasında ilişki kurarak öğrenme sürecine bütünsel bir yaklaşımla bakmasına yardımcı olabilir. Derslerde grafik düzenleyici kullanımının öğrenci başarısına olumlu etkisi olduğunun belirlendiği çalışmalar da bu ifadeyi desteklemektedir (Dönmez ve diğerleri, 2007; Strangman ve diğerleri, 2003; Meyer, 1995; Orak, Ermiş, Yeşilyurt, \& Keser, 2010; Yener \& Güzel, 2010).

Öğretim programları doğrultusunda hazırlanan ders kitapları, aynı zamanda öğretmene gerek dersini planlaması gerekse sınıf içi etkinliklerin yürütülmesi gibi birçok konuda yol göstericidir. Araştırmalar, fen konularının öğretiminde ders kitaplarının gerek sınıf içi gerek sınıf dışında en temel kaynaklar olarak kullanıldığını ve bu nedenle hala öğrenciler için oldukça büyük öneme sahip olduğunu belirtmiştir (Nakiboğlu, 2009). Köseoğlu ve diğerleri (2003), ders kitaplarının etkili bir öğrenme aracı olarak anlamlı öğrenmeyi desteklemesi gerektiğini, bu nedenle konu ile ilgili ön bilgilerin sorular, hikâyeler, gösteri deneyleri, resimler veya video gösterimleri gibi hatırlamaya yardımc1 materyaller ile aktif hâle getirilmesinin önemli olduğunu vurgulamışlardır. Bu düşüncelerden yola çıkarak ortaokul ders kitaplarının grafiksel materyalleri ne derece içerdiğini ve bu içeriğin öğrencilerin bilgilerini organize etmesine ne derece yardımcı olabileceğini bilmek oldukça önemlidir. Ülkemizde grafik 
düzenleyicilerin ders kitaplarında ne derece yer aldığını inceleyen çalışmalar oldukça azdır. Nakiboğlu ve Çamurcu (2014), Ortaöğretim 9., 10., 11. ve 12. sinıf Fizik ders kitaplarında grafik düzenleyicilere ne kadar yer verildiği ve bu grafik düzenleyicilerin türlerinin ne olduğunu belirlemeye yönelik bir çalışma yapmışlardır. Çalışmanın sonunda incelenen dört adet Fizik ders kitabında toplamda 42 tane grafik düzenleyicinin kullanıldığı ve bu sayının çok fazla olmadığı, grafik düzenleyici türü olarak da fazla çeşidin yer almadığı sonucuna ulaşılmıştır. Kitaplarda yer alan grafik düzenleyici kullanımı incelendiğinde, bu grafik düzenleyicilerinin önemli bir kısmının değerlendirme amaçlı kullanıldığı, öğrenmeye yardımcı olması amacı ile kullanımlarının çok fazla olmadığı belirlenmiştir. Nakiboğlu ve Çamurcu (2014) tarafından yürütülen bu çalışmada elde edilen bir başka sonuç, grafik düzenleyici çeşidinin en fazla 12. sınıf Fizik ders kitabında bulunduğu şeklindedir.

Yapılan alan yazın incelemesinde Ortaokul Fen Bilimleri ders kitaplarının grafik düzenleyici kullanımını inceleyen bir çalışmaya rastlanmamasından yola çıkarak bu çalışmada aşağıdaki problemlere yanıt aranmıştır:

1. Ortaokul Fen Bilimleri ders kitaplarında hangi tür grafik düzenleyiciler yer almaktadır?

2. Bu grafik düzenleyicilerin ünitelere göre dağılımı ve kullanım amacı nedir?

3. Ortaokul Fen Bilimleri ders kitaplarında yer alan grafik düzenleyicilerin sınıflara göre dağılımındaki farklılık ve benzerlikleri nelerdir?

\section{Yöntem}

\section{Araştırma Modeli}

Millî Eğitim Bakanlığı Talim Terbiye Kurulunca İlköğretim Fen Bilimleri derslerinde (5-8) okutulmak üzere uygun görülen ders kitaplarında grafik düzenleyici kullanımının araştırılmasını amaçlayan bu çalışma nitel bir araştırma olup betimsel tarama modeli kullanılmıştır. Betimsel taramalarda var olan durumlar tanımlanır (Büyüköztürk, Kılıç-Çakmak, Akgün, Karadeniz, \& Demirel, 2009).

\section{Evren ve Örneklem}

$\mathrm{Bu}$ çalışmanın evrenini 2013 Fen Bilimleri Dersi Öğretim Programına göre yazılan ortaokulların 5. 6. 7. ve 8. sinıflarında okutulan Fen Bilimleri ders kitapları ile 2017 Fen Bilimleri Dersi Öğretim Programına göre yazılan ortaokul 5. sınıf Fen Bilimleri ders kitabı oluşturmaktadır. Çalışmanın örneklemi, bu evrenden amaçsal örnekleme yoluyla seçilmiştir. Olasılıksız ve seçkisiz olmayan bir örnekleme yöntemi olan amaçsal örnekleme, yürütülen çalışmanın amacına bağlı olarak bilgi açısından zengin durumların seçilmesi ve derinlemesine araştırmasına firsat tanır (Büyüköztürk ve diğerleri, 2009).

Çalışmanın analizlerine 2016 yılında başlanmış ve 2016 yılında okutulan 8. sınıf kitabı pilot çalışma kapsamında analiz edilmiştir. Bu kitabın analiz sonuçlarının değerlendirilmesinden sonra rubriğin uygun olduğuna karar verilmiş ve tüm kitapların analizi gerçekleştirilmiştir. Asıl çalışmaya 2017 yılında başlanması nedeniyle de 2017 yılında okutulan ve 2013 yılı Fen Bilimleri Dersi Öğretim Programına göre yazılan 6., 7., ve 8. sınıf kitapları ile 2017 yılında yeni Öğretim Programının yürürlüğe girmesi ile bu programa göre yazılan 5. sınıf kitabı alınmıştır. Bütünlük sağlaması amacıyla da 
2013 Öğretim Programına göre yazılan 5. sınıf kitabının da çalışmaya dahil edilmesine karar verilmiştir. Buna bağlı olarak çalışmanın örneklemini 2013 Fen Bilimleri Dersi Öğretim Programına göre yazılan birer adet 5., 6. ve 7. sınıf Fen Bilimleri ders kitabı ile 2 adet 8. sınıf Fen Bilimleri ders kitabı, 2017 Fen Bilimleri Dersi Öğretim Programına göre yazılan bir adet 5. sinıf Fen Bilimleri ders kitabı olmak üzere 6 adet Fen Bilimleri ders kitabı oluşturmaktadır.

Ders kitaplarının ünite olarak dağılımları şu şekildedir. 2013 yılı programına göre yazılan 5. sınıf Fen Bilimleri ders kitabı 7 üniteden oluşmakta olup, bu üniteler Vücudumuzun Bilmecesini Çözelim, Kuvvetin Büyüklügüüün Ölçülmesi, Maddenin Değişimi, Işı̆̆̆ın ve Sesin Yayılması, Canlılar Dünyasını Gezelim, Yaşamın Vazgeçilmezi: Elektrik, Yer Kabuğunun Gizemi şeklindedir. 6. sınıf Fen Bilimleri ders kitab1, 8 üniteden oluşmakta ve bu üniteler sırasıyla, Vücudumuzdaki Sistemler, Kuvvet ve Hareket, Maddenin Tanecikli Yapısı, Işık ve Ses, Bitkilerde ve Hayvanlarda Üreme, Büyüme, Gelişme, Madde ve Ist, Elektriğin Iletimi, Dünya'mı, Ay ve Yaşam Kaynağımız şeklindedir. 7. sınıf Fen Bilimleri ders kitabı ise 7 üniteden oluşmaktadır. $\mathrm{Bu}$ üniteler Vücudumuzdaki Sistemler, Kuvvet ve Enerji, Manyetizma, Maddenin Yapısı ve Özellikleri, Aynalarda Yansıma ve Işı̆̆ın Soğurulması, İnsan ve Çevre İlişkileri, Elektrik Enerjisi, Güneş Sistemi ve Ötesi şeklindedir. 8. sınıf Fen Bilimleri ders kitapları, 8 ünite içermektedir. Bunlar Insanda Üreme, Büyüme, Gelişme, Basit Makineler, Maddenin Yapısı ve Özellikleri, Işı ve Ses, Canlılar ve Enerji İlişkiler, Maddenin Halleri ve Yaşamımızdaki Elektrik ve Deprem ve Hava Olayları üniteleridir.

2017 yılı programına göre yazılan 5. sınıf Fen Bilimleri ders kitabı 8 üniteden oluşmakta olup, bu üniteler Güneş, Dünya, Ay, Canlılar Dünyası, Kuvvetin Ölçülmesi, Madde ve Değişim, Işı̆̆ın Yayılması, İnsan ve Çevre, Elektrik Devre Elemanları, Fen ve Mühendislik Uygulamaları şeklindedir.

\section{Veri Toplama Süreci ve Analizi}

Çalışmanın veri toplama yöntemi, belgesel tarama yöntemidir (Karasar, 2005). Araştırılması amaçlanan olgu ya da olgular hakkında bilginin yer aldığı yazılı materyallerin analizinin gerçekleştirildiği bu yöntem, aynı zamanda doküman incelemesi yöntemi olarak da bilinir (Yıldırım \& Şimşek, 2011).

$\mathrm{Bu}$ amaçla daha önce Çamurcu ve Nakiboğlu (2014) tarafından Fizik kitaplarının grafik düzenleyicilere göre analizinin yapıldığı çalışmada kullanılan yol izlenmiştir. $\mathrm{Bu}$ çalışmada araştırmacılarca grafik düzenleyici sınıflandırılması için geliştirilen kavram haritası kullanılmıştır. Bu çalışmada, hazırlanan bu kavram haritası tekrar gözden geçirilmiş ve küçük düzeltmelerle yeniden oluşturulmuştur (Şekil 1). Böylece oluşturulan kavram haritasında yer alan grafik düzenleyici sınıflandırması kullanılarak, ders kitaplarının analizi şu şekilde gerçekleştirilmiştir: İlk basamakta grafik düzenleyicilerin hangi amaçla hazırlandıkları incelenerek içerik açısından, grafik düzenleyici hazırlanırken kullanılan çizim türü incelenerek biçim açısından grafik düzenleyiciler belirlenmiştir. Son olarak da kitaplarda grafik düzenleyicilerin kullanım amacına ilişkin analiz gerçekleştirilmiştir.

Kitap analizi güvenirliğinin sağlanması şu şekilde gerçekleştirilmiştir: Geliştirilen kavram haritasına göre analiz, önce çalışmanın ikinci yazarı tarafından yapılmıştır. Bu analiz sırasında çelişkili kalan durumlar, konu alanı uzmanı ilk yazar ile tartışılarak sonuçlandırılmıştır. Bu şekilde elde edilen analiz sonuçları tablolaştırılmıştır. 
Son olarak iki ay kadar sonra iki yazar birlikte tüm analizi tekrar gözden geçirerek hiçbir çelişki kalmayacak şekilde analizi son hale getirmişlerdir.

\section{Verilerin Sunumu}

Bulgular, grafik düzenleyicilerin yer aldığı sayfa numaraları da yer alacak şekilde ünitede bulunduğu yer, kullanım amacı, ünite numarasını da gösterecek şekilde tablolaştırılarak sunulmuştur. Ayrıca, veri sunumu sırasında gerekli yerlerde örnekler ve doğrudan alıntılara yer verilmiştir.

Şekil 1. Grafik Düzenleyicilerin Sınıflandırılması

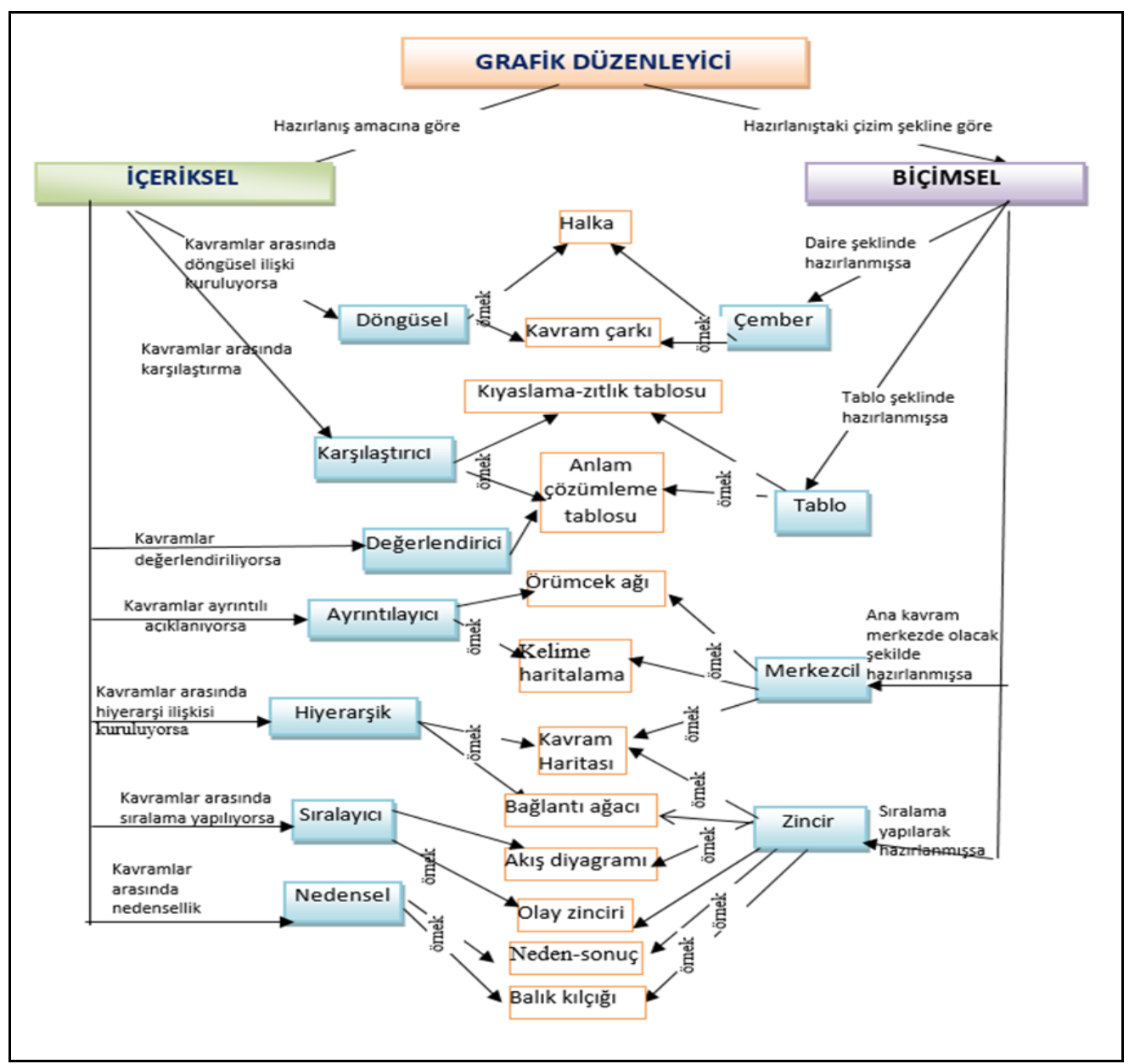

Uyarlandı̆̆ı yayın. (Nakiboğlu \& Çamurcu, 2014).

\section{Bulgular}

Bulgular kısmında ilk olarak, birinci ve ikinci araştırma problemi olan, 5., 6., 7. ve 8. sınıf Fen Bilimleri ders kitaplarında hangi tür grafik düzenleyicilerin yer aldığı, bu grafik düzenleyicilerin ünitelere göre dağılımı nasıl olduğu ve kullanım amacının ne olduğu sorularına yanıt bulmak için her bir sınıfa ait ders kitabı analiz sonuçları ayrı alt başlıklar altında sunulacaktır. Daha sonra, üçüncü araştırma problemi olan 5., 6., 7. ve 8. sınıf Fen Bilimleri ders kitaplarında yer alan grafik düzenleyicilerin sınıflara göre dağılımındaki farklılık ve benzerliklerin neler olduğuna yönelik, 6 ders kitabına ilişkin analiz sonuçlarının kıyaslandığı bulgular sunulacaktır. 


\section{Sınıf Fen Bilimleri Ders Kitaplarının Analizine Ait Bulgular}

Çalışmada hem 2013 hem de 2017 y1lı Fen Bilimleri Dersi Öğretim Programlarına göre yazılan 5. sınıf ders kitaplarının analiz edilmesi nedeniyle, 5. sınıflara ait 2 kitap analiz sonucu ayrı ayrı sunulmuştur. Tablo 1'de 2013 yılı Fen Bilimleri Dersi Öğretim Programına göre hazırlanan 5. sınıf ders kitabında grafik düzenleyicilerin nasıl kullanıldığına yönelik analiz ile elde edilen bulgular verilmiştir.

Tablo 1

2013 Yılı Programına göre Hazırlanan 5. Sinıf Fen Bilimleri Ders Kitabında Grafik Düzenleyici Kullanımına İlişkin Bulgular

\begin{tabular}{|c|c|c|c|c|c|c|}
\hline $\begin{array}{c}\text { İçeriksel } \\
\text { Tür }\end{array}$ & $\begin{array}{c}\text { Biçimsel } \\
\text { Tür }\end{array}$ & $\begin{array}{c}\text { Grafik } \\
\text { Düzenleyici }\end{array}$ & Ünite & Konum & $\begin{array}{c}\text { Kullanım } \\
\text { Amacı }\end{array}$ & $\begin{array}{c}\text { Sayfa } \\
\text { No }\end{array}$ \\
\hline \multirow{3}{*}{ Hiyerarşik } & \multirow{3}{*}{$\begin{array}{l}\text { Merkez- } \\
\text { cil }\end{array}$} & $\begin{array}{c}\text { Kavram } \\
\text { Ağ1 }\end{array}$ & 1 & $\begin{array}{c}\text { Konu } \\
\text { İçi }\end{array}$ & Sinıflama & 31 \\
\hline & & $\begin{array}{l}\text { Kavram } \\
\text { Haritası }\end{array}$ & 4 & $\begin{array}{l}\text { Konu } \\
\text { Sonu }\end{array}$ & $\begin{array}{l}\text { Değerlen- } \\
\text { dirme }\end{array}$ & 119 \\
\hline & & $\begin{array}{l}\text { Kavram } \\
\text { Haritası }\end{array}$ & 7 & $\begin{array}{l}\text { Konu } \\
\text { Sonu }\end{array}$ & Pekiştirme & 168 \\
\hline \multirow{3}{*}{ Siralayıcı } & \multirow{3}{*}{ Zincir } & $\begin{array}{c}\text { Akış } \\
\text { Diyagramı }\end{array}$ & 1 & $\begin{array}{c}\text { Konu } \\
\text { İçi }\end{array}$ & Pekiştirme & 33 \\
\hline & & $\begin{array}{c}\text { Akış } \\
\text { Diyagramı }\end{array}$ & 3 & $\begin{array}{l}\text { Konu } \\
\text { Sonu }\end{array}$ & $\begin{array}{l}\text { Değerlen- } \\
\text { dirme }\end{array}$ & 91 \\
\hline & & $\begin{array}{c}\text { Akış } \\
\text { Diyagramı }\end{array}$ & 7 & $\begin{array}{c}\text { Konu } \\
\text { İçi }\end{array}$ & $\begin{array}{l}\text { Siralama } \\
\text { gösterme }\end{array}$ & 172 \\
\hline \multirow{3}{*}{$\begin{array}{c}\text { Ayrnntıla- } \\
\text { yıc1 }\end{array}$} & \multirow{3}{*}{ Tablo } & $\begin{array}{l}\text { Minyatür } \\
\text { Resim }\end{array}$ & 1 & $\begin{array}{c}\text { Konu } \\
\text { İçi }\end{array}$ & $\begin{array}{c}\text { Görsel Ön } \\
\text { Düzenleyici }\end{array}$ & 16 \\
\hline & & $\begin{array}{c}\text { Anlam Çöz. } \\
\text { Tab. }\end{array}$ & 4 & $\begin{array}{l}\text { Ünite } \\
\text { Sonu }\end{array}$ & $\begin{array}{c}\text { Değerlen- } \\
\text { dirme }\end{array}$ & 118 \\
\hline & & $\begin{array}{l}\text { Minyatür } \\
\text { Resim }\end{array}$ & 5 & $\begin{array}{c}\text { Konu } \\
\text { Başı }\end{array}$ & $\begin{array}{c}\text { Görsel Ön } \\
\text { Düzenleyici }\end{array}$ & 123 \\
\hline Nedensel & Tablo & $\begin{array}{l}\text { Neden- } \\
\text { Sonuc }\end{array}$ & 7 & $\begin{array}{l}\text { Konu } \\
\text { İçi }\end{array}$ & Pekiştirme & 189 \\
\hline
\end{tabular}

Tablo 1 incelendiğinde 2013 yılı programına göre hazırlanan 5. sınıf ders kitabında yer alan grafik düzenleyicilerin içeriksel tür olarak sıralayıcı, hiyerarşik, ayrıntılayıcı ve nedensel alt kategorilerinde toplandı̆̆ı; grafik düzenleyici biçimsel türü olarak da merkezcil, zincir ve tablo alt kategorilerinde toplandığ 1 görülmektedir. 5. sınıf kitabında toplam 10 grafik düzenleyicinin yer aldığı ve bunların, 3 tanesinin akış diyagramı, 1 tanesinin anlam çözümleme tablosu, 2 tanesinin minyatür resim, 1 tanesinin kavram ağı, 2 tanesinin kavram haritası ve 1 tanesinin de neden-sonuç diyagramı olduğu belirlenmiştir. Ayrıca Tablo 1'den grafik düzenleyicilerin 5 tanesinin konu içerisinde, 3 tanesinin konu sonunda, 1 tanesinin ünite sonunda ve 1 tanesinin de konu başında yer aldığ1 görülmektedir. Kullanım amaçları incelendiğinde 2 tanesinin görsel ön düzenleyici olarak kitapta yer aldığı belirlenmiştir. Diğerlerinden 3 tanesinin 
değerlendirme amaçlı konu sonunda, 3 tanesinin pekiştirme amaçlı kitabın farklı yerlerinde, 1 tanesinin sınıflandırma ve 1 tanesinin de sıralama gösterme amaçlı konu içinde kullanıldığı görülmüştür.

2013 y1lı programına göre hazırlanan 5. sinıf ders kitabında yer alan grafik düzenleyicilere örnek olarak neden-sonuç diyagramı ele alınabilir. Herhangi bir konudaki düşünce ve fikirleri organize etmede kullanılan neden-sonuç diyagramı türündeki grafik düzenleyicinin, kitapda yapılan bazı işlemlerinin çevre kirliliği ile ilgili sonuçlarını özetlemek ve böylece konunun pekiştirilmesini sağlamak amacı ile konu içinde kullanıldığı belirlenmiştir.

5. sınıf fen bilimleri kitabında yer alan kavram ağı, 1. ünite olan "Vücudumuzun Bilmecesini Çözelim" ünitesinin "Dişlerimiz" konusu içinde görevlerine göre dişleri sınıflandırmak için kullanılmıştır. Kavram haritaları ise bir tanesi 4. ünite olan "Işs̆̆ı̆ ve Sesi Yayılması" ünite sonu değerlendirme sorularında "Ses" konusunu pekiştirmek için kullanılmıştır. Diğer kavram haritası ise 7. ünite olan "Yer Kabuğunun Gizemi" ünitesinin "Kayaç, Mineral ve Madenleri Tanıyalım" konusunun sonunda maden, mineral, kayaç arasındaki ilişkiyi pekiştirmek için kullanılmıştır. Akış diyagramı biçimindeki grafik düzenleyici ise; 1. ünite olan "Vücudumuzun Bilmecesini Çözelim" ünitesinin "Dişlerimiz" konusu içinde doğru diş firçalama tekniğinin basamaklarını sıralamak amacıyla kullanılmıştır.

Diğer akış diyagramlarından biri, 3.ünite olan "Maddenin Değişimi”" ünite sonu değerlendirme sorularında hal değişim olaylarını pekiştirmek için; ikinci akış diyagramı ise 7. ünite olan "Yer Kabuğunun Gizemi" ünitesinin "Fosiller" konusu içinde fosil oluşumu basamakları sırasını göstermek amacıyla kullanılmıştır.

Tablo 2'de 2017 yılı Fen Bilimleri Dersi Öğretim Programına göre hazırlanan 5. sınıf ders kitabında grafik düzenleyicilerin nasıl kullanıldığına yönelik analiz ile elde edilen bulgular verilmiştir. 
Tablo 2

2017 Yılı Programına göre Hazırlanan 5. Sinıf Fen Bilimleri Ders Kitabında Grafik Düzenleyici Kullanımına İlişkin Bulgular

\begin{tabular}{|c|c|c|c|c|c|c|}
\hline $\begin{array}{c}\text { İçeriksel } \\
\text { Tür }\end{array}$ & $\begin{array}{l}\text { Biçimsel } \\
\text { Tür }\end{array}$ & $\begin{array}{c}\text { Grafik } \\
\text { Düzenleyici }\end{array}$ & Ünite & Konum & $\begin{array}{c}\text { Kullanım } \\
\text { Amacı }\end{array}$ & $\begin{array}{c}\text { Sayfa } \\
\text { No }\end{array}$ \\
\hline $\begin{array}{c}\text { Hiyerarşi } \\
\text { k }\end{array}$ & Zincir & $\begin{array}{l}\text { Bağlantı } \\
\text { Ağac1 }\end{array}$ & 1 & $\begin{array}{c}\text { Ünite } \\
\text { İçi }\end{array}$ & Sinıflama & 32 \\
\hline \multirow{7}{*}{$\begin{array}{c}\text { Ayrint1- } \\
\text { layıc1 }\end{array}$} & \multirow{7}{*}{ Tablo } & \multirow{7}{*}{$\begin{array}{c}\text { Anlam Çöz. } \\
\text { Tab. } \\
\text { Minyatür } \\
\text { Resim } \\
\text { Anlam Çöz. } \\
\text { Tab. } \\
\text { Anlam Çöz. } \\
\text { Tab. }\end{array}$} & 3 & \multirow{2}{*}{$\begin{array}{l}\text { Ünite } \\
\text { Sonu }\end{array}$} & Etkinlik & 99 \\
\hline & & & 7 & & Pekiştirme & 246 \\
\hline & & & 2 & Konu & Değerlen- & 78 \\
\hline & & & 8 & & dirme & 269 \\
\hline & & & & Unite & Değerlen- & \\
\hline & & & & Ünite & & \\
\hline & & & & Sonu & & \\
\hline \multirow{3}{*}{$\begin{array}{c}\text { Karşılaş- } \\
\text { tırıcı }\end{array}$} & \multirow{3}{*}{ Tablo } & \multirow{3}{*}{$\begin{array}{c}\text { Kiyaslama/ } \\
\text { Zitlık }\end{array}$} & \multirow{3}{*}{4} & \multirow{3}{*}{$\begin{array}{c}\text { Konu } \\
\text { İçi }\end{array}$} & Benzerlik & \\
\hline & & & & & ve & 146 \\
\hline & & & & & $\begin{array}{l}\text { Farkl1lik } \\
\text { Gösterme }\end{array}$ & \\
\hline Döngüsel & Çember & Halka & 8 & Konu & Özetleme & 271 \\
\hline & & & & İçi & & \\
\hline
\end{tabular}

2017 y1lı Fen Bilimleri Dersi Öğretim Programına göre hazırlanan 5. sınıf ders kitabına ait analiz sonuçlarının yer aldığı Tablo 2 incelendiğinde, grafik düzenleyicilerin içeriksel tür olarak ayrıntılayıcı, karşılaştırıcı, hiyerarşik ve döngüsel alt kategorilerinde toplandığ 1 ; grafik düzenleyici biçimsel türü olarak da zincir, tablo ve çember alt kategorilerinde toplandığ 1 görülmektedir. 5. sınıf kitabında toplam 7 grafik düzenleyicinin yer aldığ 1 ve bunlardan 3 tanesinin anlam çözümleme tablosu, 1 tanesinin minyatür resim, 1 tanesinin bağlantı ağacı, 1 tanesinin kıyaslama-zıtlık tablosu ve 1 tanesinin de halka olduğu belirlenmiştir. Grafik düzenleyicilerin 3 tanesi konu içerisinde, 3 tanesi ünite sonunda ve 1 tanesinin de ünite içerisinde yer aldığ 1 Tablo 2'den görülmektedir.

5. sınıf Fen Bilimleri Dersi kitabında yer alan bağlantı ağacı isimli grafik düzenleyici 1. ünite olan “Güneş, Dünya, Ay” ünitesinin "Ay’ın Evreleri” konusu içinde Ay’ın evrelerini sınıflandırmak amacıyla kullanılmıştır. Kitapta yer alan 3 adet anlam çözümleme tablosu türündeki grafik düzenleyicisinden ilki, 2. ünite olan "Canlılar Dünyası" ünite sonu değerlendirme çalışmalarında ve "Bitkiler" konusunu pekiştirmek için kullanılırken ikici anlam çözümleme tablosu 3. ünite olan "Kuvvetin Ölçülmesi" ünitesinin "Sürtünme Kuvveti” konusunun sonunda ve konuyu pekiştirmek amaçlı etkinlik içinde kullanılmıştır. Son anlam çözümleme tablosu, 8. ünite olan "Fen ve Mühendislik Uygulamaları" ünitesinin sonunda değerlendirme amaçlı kullanılmıştır. Kitapta yer alan 1 adet minyatür resim adlı grafik düzenleyici ise 7. ünite olan "Elektrik Devre Elemanları" ünitesinin içinde "Devre Elemanları" konusunda ve pekiştirme amaçlı kullanılmıştır. 
Kitapta 4. ünite olan "Madde ve Değişim" ünitesinde "Isı ve Sicaklık" konusunda isı ve sıcaklık kavramlarının benzerlik ve farklılıklarını göstermek amacıyla kıyaslama- zıtlık matrisi grafik düzenleyicisi kullanılmıştır. 8. ünite olan "Fen ve Mühendislik Uygulamaları" ünitesinin "Mühendis Nasıl Çalışır? konusunu özetlemek amacıyla bir halka grafik düzenleyicisi kullanılmıştır.

\section{Sınıf Fen Bilimleri Ders Kitabı Analizine Ait Bulgular}

2013 yılı Fen Bilimleri Dersi Öğretim Programına göre hazırlanan 6. sınıf ders kitabında grafik düzenleyicilerin nasıl kullanıldığına yönelik analiz ile elde edilen bulgular Tablo 3'de verilmiştir.

Tablo 3

2013 Yılı Programına göre Hazırlanan 6. Sinıf Fen Bilimleri Ders Kitabında Grafik Düzenleyici Kullanımına İlişkin Bulgular

\begin{tabular}{|c|c|c|c|c|c|c|}
\hline $\begin{array}{l}\text { İçeriksel } \\
\text { Tür }\end{array}$ & $\begin{array}{c}\text { Biçimsel } \\
\text { Tür }\end{array}$ & $\begin{array}{c}\text { Grafik } \\
\text { Düzenleyici }\end{array}$ & Ünite & Konum & $\begin{array}{l}\text { Kullanım } \\
\text { Amacı }\end{array}$ & $\begin{array}{c}\text { Sayfa } \\
\text { No }\end{array}$ \\
\hline \multirow{4}{*}{ Sıralayıcı } & \multirow{4}{*}{ Zincir } & Olay Zinciri & 1 & Konu İçi & Özetleme & 25 \\
\hline & & Olay Zinciri & 1 & Konu İçi & Pekiştirme & 58 \\
\hline & & Olay Zinciri & 5 & Konu İçi & Özetleme & $\begin{array}{l}160- \\
163\end{array}$ \\
\hline & & Olay Zinciri & 5 & Konu İçi & Özetleme & 151 \\
\hline \multirow{3}{*}{$\begin{array}{l}\text { Ayrint1- } \\
\text { layıc1 }\end{array}$} & \multirow[t]{2}{*}{ Tablo } & $\begin{array}{c}\text { Anlam Çöz. } \\
\text { Tab. }\end{array}$ & 1 & $\begin{array}{c}\text { Konu } \\
\text { Etkinliği }\end{array}$ & Etkinlik & 26 \\
\hline & & $\begin{array}{c}\text { Anlam Çöz. } \\
\text { Tab. }\end{array}$ & 5 & Etkinlik & $\begin{array}{l}\text { Değerlen- } \\
\text { dirme }\end{array}$ & 169 \\
\hline & $\begin{array}{l}\text { Merkez- } \\
\text { cil }\end{array}$ & Kavram Ağ & 1 & Konu İçi & Sinıflama & 59 \\
\hline Döngüsel & Çember & $\begin{array}{l}\text { Venn } \\
\text { Şeması }\end{array}$ & 2 & Etkinlik & $\begin{array}{l}\text { Değerlen- } \\
\text { dirme }\end{array}$ & 81 \\
\hline
\end{tabular}

Tablo 3 incelendiğinde, 2013 yılı Fen Bilimleri Dersi Öğretim Programına göre hazırlanan 6. sınıf ders kitabında yer alan grafik düzenleyicilerin içeriksel tür olarak sıralayıcı, ayrıntılayıcı ve döngüsel alt kategorilerinde yer aldığı, grafik düzenleyici biçimsel türü olarak da zincir, tablo, merkezcil ve çember alt kategorilerinde toplandiğ 1 görülmektedir. 6. sınıf ders kitabında toplam 8 grafik düzenleyicinin yer aldığı ve bunların, 4 tanesinin olay zinciri, 2 tanesinin anlam çözümle tablosu, 1 tanesinin kavram ăgl ve 1 tanesinin de venn şeması olduğu bulunmuştur. Grafik düzenleyicilerin 5 tanesinin konu içerisinde ve diğer 3 tanesinin de etkinlikte yer aldığ 1 Tablo 2'den görülmektedir.

2013 yılı Fen Bilimleri Dersi Öğretim Programına göre hazırlanan 6. sınıf ders kitabında yer alan olay zinciri türündeki 5 grafik düzenleyicinin "Vücudumuzdaki Sistemler", "Bitkilerde ve Hayvanlarda Üreme, Büyüme, Gelişme” ünitelerinde konu içinde konuyu özetlemek ve pekiştirmek amacıyla kullanılmıştır. Kitapta yer alan 2 adet 
anlam çözümleme isimli grafik düzenleyicisi ise "Vücudumuzdaki Sistemler", "Bitkilerde ve Hayvanlarda Üreme, Büyüme, Gelişme" ünitelerinin değerlendirme sorularında yer aldığı belirlenmiştir. "Vücudumuzdaki Sistemler" ünitesinde "Damarlar" konusunu sınıflandırmak için kavram ăgl kullanılmıştır. 2. ünitenin değerlendirme çalışmalarında yer alan venn şeması ise "Dengelenmiş ve Dengelenmemiş Kuvvetler" konusunda benzerlik ve farklılıkları göstermek için kullanılmıştır.

\section{Sınıf Fen Bilimleri Ders Kitabı Analizine Ait Bulgular}

2013 yılı Fen Bilimleri Dersi Öğretim Programına göre hazırlanan ve MEB tarafından 2016 -2017 Eğitim-Öğretim yılında 7. sınıflarda ders kitabı olarak okutulmak üzere onaylanmış olan, Fen Bilimleri Ders kitabında grafik düzenleyicilerin nasıl kullanıldığına yönelik analiz ile elde edilen bulgular Tablo 4'de verilmiştir.

Tablo 4

2013 Yılı Programına göre Hazırlanan 7. Sinıf Fen Bilimleri Ders Kitabında Grafik Düzenleyici Kullanımına İlişkin Bulgular

\begin{tabular}{|c|c|c|c|c|c|c|}
\hline İçeriksel Tür & $\begin{array}{l}\text { Biçimsel } \\
\text { Tür }\end{array}$ & $\begin{array}{c}\text { Grafik } \\
\text { Düzenleyici }\end{array}$ & Ünite & Konum & $\begin{array}{c}\text { Kullanım } \\
\text { Amacı }\end{array}$ & $\begin{array}{c}\text { Sayfa } \\
\text { No }\end{array}$ \\
\hline Hiyerarşik & Merkez-cil & $\begin{array}{c}\text { Kavram Ă̆ı } \\
\text { Bağlantı Ağacı } \\
\text { Kavram Haritası } \\
\text { Bağlantı Ağacı } \\
\text { Kavram Haritası } \\
\text { Kavram Haritası }\end{array}$ & $\begin{array}{l}1 \\
1 \\
1 \\
1 \\
1 \\
2\end{array}$ & $\begin{array}{c}\text { Konu Sonu } \\
\text { Konu İçi } \\
\text { Konu Sonu } \\
\text { Konu Sonu } \\
\text { Konu Sonu } \\
\text { Konu Sonu }\end{array}$ & $\begin{array}{l}\begin{array}{c}\text { Değerlen- } \\
\text { dirme }\end{array} \\
\text { Pekiştirme } \\
\text { Pekiştirme } \\
\text { Pekiştirme } \\
\text { Pekiştirme } \\
\text { Pekiştirme }\end{array}$ & $\begin{array}{l}22 \\
31 \\
41 \\
60 \\
61 \\
101\end{array}$ \\
\hline Siralayıcı & Zincir & $\begin{array}{c}\text { Olay Zinciri } \\
\text { Kavram Haritası } \\
\text { Süreklilik Ö. }\end{array}$ & $\begin{array}{l}1 \\
3 \\
3\end{array}$ & $\begin{array}{c}\text { Konu İçi } \\
\text { Ünite Sonu } \\
\text { Ünite Sonu }\end{array}$ & $\begin{array}{c}\text { Özetleme } \\
\text { Pekiştirme } \\
\text { Süreci } \\
\text { Gösterme }\end{array}$ & $\begin{array}{c}45-46-47 \\
155 \\
155\end{array}$ \\
\hline Nedensel & Tablo & $\begin{array}{c}\text { Kiyaslama/ } \\
\text { Zitlık }\end{array}$ & 2 & Konu İçi & Özetleme & 72 \\
\hline
\end{tabular}

Tablo 4 incelendiğinde 2013 yılı Fen Bilimleri Dersi Öğretim Programına göre hazırlanan 7. sınıf ders kitabındaki grafik düzenleyicilerin içeriksel tür şeklinde hiyerarşik, sıralayıcı ve nedensel alt kategorilerinde yer aldığ ; biçimsel tür olarak da merkezci, zincir ve tablo alt kategorilerinde yer aldığı görülmektedir. 7. sınıf kitabında toplam 12 grafik düzenleyicinin yer aldığ 1 ve bunların 4 tanesinin kavram haritası, 2 tanesinin bağlantı ağac1, 1 tanesinin kavram ağı, 1 tanesinin olay zinciri, 1 tanesinin süreklilik ölçeği, 1 tanesinin de kıyaslama zitlık tablosu olduğu belirlenmiştir. Tablo 4'den grafik düzenleyicilerin konumları incelendiğinde 5 tanesinin konu içerisinde, 5 tanesinin konu sonunda ve 2 tanesinin de ünite sonunda yer aldığ görülmektedir. 
2013 yılı Fen Bilimleri Dersi Öğretim Programına göre hazırlanan 7. sınıf kitabında kullanılan dört adet kavram haritasının hepsinin farklı 4 konunun sonunda ve pekiştirme amaçlı hazırlandığ 1 belirlenmiştir. 1. ünite de yer alan "Sindirim Sistemi" konu sonu etkinliğinde değerlendirme amaçlı kavram ağı kullanılmıştır. Kitapta yer alan 3 adet olay zincirinin, 1. ünitenin "Duyu Organları" adlı konusunun içinde görme, işitme ve koku alma olaylarının izlediği yolu özetlemek amaciyla kullanıldığ görülmüştür.

3. ünite olan "Maddenin Yapısı ve Özellikleri" ünitesinin sonunda "Neler Öğrendik" adlı kısımda atom modellerinin tarihsel gelişim sürecini göstermek için kullanılan süreklilik ölçeği adlı bir grafik düzenleyici yer almaktadır. Kıyaslama zıtlık tablosunun "Kuvvet ve Enerji" ünitesinde kütle ve ağırlık konusunu özetlemek için kullanıldığı belirlenmiştir.

\section{Sınıf Fen Bilimleri Ders Kitaplarının Analizine Ait Bulgular}

2013 yılı Fen Bilimleri Dersi Öğretim Programına göre hazırlanan ve analiz gerekçesi yöntem bölümünde açıklanan 2 adet 8. sınıf Fen Bilimleri Ders kitabından ilki, MEB tarafından 2016-2017 yılında 8. sınıflarda ders kitabı olarak okutulmak üzere hazırlanmış olan kitaptır. Bu kitapta grafik düzenleyici kullanımına yönelik analize ait bulgular Tablo 5'de sunulmuştur.

Tablo 5

2016-2017 Eğitim-Öğretim Yllında Okutulan8. Sınıf Fen Bilimleri Ders Kitabında Grafik Düzenleyici Kullanımına İlişkin Bulgular

\begin{tabular}{ccccccc}
\hline İçeriksel Tür & $\begin{array}{c}\text { Biçimsel } \\
\text { Tür }\end{array}$ & $\begin{array}{c}\text { Grafik } \\
\text { Düzenleyici }\end{array}$ & Ünite & Konum & $\begin{array}{c}\text { Kullanım } \\
\text { Amacı }\end{array}$ & $\begin{array}{c}\text { Sayfa } \\
\text { No }\end{array}$ \\
\hline Sıralayıcı & Zincir & Olay Zinciri & 1 & Konu Sonu & Özetleme & 28 \\
\hline Karşıslaştı-rıc1 & Tablo & $\begin{array}{c}\text { Kiyaslama/ } \\
\text { Zttlık }\end{array}$ & 1 & Konu İçi & Özetleme & 28 \\
& & & & & & \\
\hline
\end{tabular}

Tablo 5 incelendiğinde 2016-2017 Eğitim-Öğretim y1lında okutulan 8. sinıf ders kitabında yer alan grafik düzenleyicilerin içeriksel tür olarak sıralayıcı ve karşılaştırıcı alt kategorilerinde toplandığı; biçimsel tür olarak da zincir ve tablo alt kategorilerinde toplandığ1 görülmektedir. 8. sınıf kitabında toplam 2 grafik düzenleyicinin yer aldığ ve bunların 1 tanesinin olay zinciri, diğerinin de kıyaslama zitlık tablosu olduğu belirlenmiştir. Ders kitabı içerisinde grafik düzenleyicilerin yerleşim yerine baktığımızda, olay zincirinin konu sonunda ve kıyaslama zitlık tablosunun da konu içinde yer aldığı görülmektedir. Her ikisinin de özetleme amaçlı kullanıldığ 1 belirlenmiştir. Bunlardan olay zincirinin, "İnsanda Üreme, Büyüme, Gelişme" ünitesinin bölünme evrelerini özetlemek amacıyla kullanıldı̆̆ zitlık tablosunun 1. ünite olan “İnsanda Üreme, Büyüme, Gelişme” ünitesinin içerisinde mayoz ve mitoz bölünme arasındaki farklılıkları göstermek amacıyla kullanıldığ 1 görülmüştür. 
2013 yılı Fen Bilimleri Dersi Öğretim Programına göre hazırlanan ve MEB tarafindan 2017-2018 yılında 8. sinıflarda ders kitabı olarak okutulmak üzere hazırlanmış olan kitabın grafik düzenleyicilerin kullanımına ilişkin analizi sonucunda elde edilen bulgular Tablo 6'da verilmiştir.

Tablo 6

2017-2018 Ĕ̈itim-Öğretim Yılında Okutulan 8. Sinıf Fen Bilimleri Ders Kitabında Grafik Düzenleyici Kullanımına İlişkin Bulguları

\begin{tabular}{|c|c|c|c|c|c|c|}
\hline İçeriksel Tür & Biçimsel Tür & $\begin{array}{c}\text { Grafik } \\
\text { Düzenleyici }\end{array}$ & Ünite & Konum & $\begin{array}{l}\text { Kullanım } \\
\text { Amacı }\end{array}$ & $\begin{array}{c}\text { Sayfa } \\
\text { No }\end{array}$ \\
\hline \multirow{2}{*}{ Siralayıcı } & \multirow{2}{*}{ Zincir } & Olay Zinciri & 1 & Konu İçi & Özetleme & 22 \\
\hline & & Olay Zinciri & 3 & Konu İçi & Özetleme & 85 \\
\hline \multirow{2}{*}{$\begin{array}{c}\text { Karşılaşt1- } \\
\text { ric1 }\end{array}$} & \multirow[b]{2}{*}{ Tablo } & $\begin{array}{l}\text { Kiyaslama/ } \\
\text { Zitlık }\end{array}$ & 4 & Ünite Sonu & $\begin{array}{l}\text { Farlılık } \\
\text { Göste- }\end{array}$ & 122 \\
\hline & & $\begin{array}{c}\text { Anlam Çöz. } \\
\text { Tab. }\end{array}$ & 3 & Etkinlik & $\begin{array}{c}\text { me } \\
\text { Pekiş-tirme }\end{array}$ & 67 \\
\hline \multirow[t]{2}{*}{ Döngüsel } & Çember & Halka & 5 & Konu İçi & Özetleme & 137 \\
\hline & & & & & & 139 \\
\hline $\begin{array}{l}\text { Ayrint1- } \\
\text { layıc1 }\end{array}$ & Merkezcil & Zihin Haritas & 5 & Konu İçi & Pekiş-tirme & 143 \\
\hline
\end{tabular}

Tablo 6 incelendiğinde 2017-2018 Eğitim-Öğretim y1lında okutulan 8. sinıf ders kitabında yer alan grafik düzenleyicilerin içeriksel tür olarak sıralayıcı, karşılaştırıcı, döngüsel ve ayrıntılayıcı alt kategorilerinde toplandığı; biçimsel tür olarak da zincir, tablo, çember ve merkezcil alt kategorilerinde toplandığı görülmektedir. 8. sinıf kitabında toplam 6 grafik düzenleyicinin yer aldığı ve bunların 2 tanesinin olay zinciri, 1 tanesinin kıyaslama zitlık tablosu, 1 tanesinin anlam çözümleme tablosu, 1 tanesinin halka ve 1 tanesinin de zihin haritası olduğu belirlenmiştir. Grafik düzenleyicilerin 4 tanesi konu içerisinde, 1 tanesinin ünite sonunda, 1 tanesi de etkinlikte olduğu görülmektedir.

8. sinıf Fen Bilimleri ders kitabında yer alan 2 adet olay zincirinden ilkinin, “İnsanda Üreme, Büyüme, Gelişme” ünitesinin bölünme evrelerini özetlemek amacıyla kullanıldığı belirlenmiştir. Diğerinin "Maddenin Yapısı ve Özellikleri” ünitesinde asit yağmurları konusunu özetlemek için kullanıldı̆̆ 1 görülmektedir. Kıyaslama zitlık tablosu ise 4. ünite olan "Işık ve Ses" ünitesinin sonunda 1şık ve ses kavramlarının benzerlik ve farklılıklarını göstermek için kullanılmaktadır. Kitapta yer alan tek anlam çözümleme tablosu etkinlikte konuyu pekiştirmek amaçlı kullanılmıştır. Halka şeklindeki grafik düzenleyici 5. ünite olan “Canlılar ve Enerji İlişkileri” ünitesinin "Madde Döngüleri” konusunu özetlemek amacıyla kullanılmıştır. Aynı ünitede ozonu etkileyen unsurlar konusunu pekiştirmek amacı ile bir zihin haritası kullanıldı̆̆ belirlenmiştir. 


\section{Fen Bilimleri Ders Kitaplarının Karşılaştırılmasına Yönelik Bulgular}

Ortaokul Fen Bilimleri ders kitaplarında yer alan grafik düzenleyicilerin sinıf düzenlerine ait dağılımlarındaki farklılık ve benzerliklerinin ortaya çıkarılması için yazılan üçüncü araştırma problemine yanıt oluşturmak üzere öncelikle bütün kitapların grafik düzenleyicilerinin içeriksel ve biçimsel türleri açısından karşılaştırılmasına yönelik bir tablo hazırlanmıştır. İlgili bulgular Tablo 7'de sunulmuştur.

Tablo 7

5., 6., 7. ve 8. Sinıf Fen Bilimleri Ders Kitaplarında kullanılan Grafik Düzenleyicilerin İçeriksel ve Biçimsel Türlerinin Sayısal Dă̆llımına İlişkin Bulgular

\begin{tabular}{|c|c|c|c|c|c|c|c|c|}
\hline \multirow[b]{3}{*}{$\begin{array}{c}\text { İçeriksel } \\
\text { Tür }\end{array}$} & \multicolumn{8}{|c|}{ Sınıf Düzeyi } \\
\hline & \multirow[b]{2}{*}{$\begin{array}{c}\text { Biçimsel } \\
\text { Tür }\end{array}$} & \multirow{2}{*}{$\begin{array}{c}5 \\
2013^{*}\end{array}$} & \multirow{2}{*}{$\begin{array}{c}5 \\
2017^{*}\end{array}$} & \multirow[t]{2}{*}{6} & \multirow[t]{2}{*}{7} & \multirow{2}{*}{$\begin{array}{c}8 \\
\mathrm{GY}^{* *}\end{array}$} & \multirow{2}{*}{$\begin{array}{c}8 \\
\mathrm{BY}^{* *}\end{array}$} & \multirow{2}{*}{$\begin{array}{l}\text { Toplam } \\
\text { G.D. }{ }^{* * *} \\
\text { Sayısı }\end{array}$} \\
\hline & & & & & & & & \\
\hline Hiyerar-şik & Merkez-cil & 3 & 1 & - & 6 & - & - & 10 \\
\hline Siralayıcı & Zincir & 3 & - & 4 & 5 & 1 & 2 & 15 \\
\hline \multirow{2}{*}{$\begin{array}{l}\text { Ayrint1- } \\
\text { layıc1 }\end{array}$} & Tablo & 3 & 4 & 2 & - & - & - & 9 \\
\hline & Merkez-cil & - & - & 1 & - & - & 1 & 2 \\
\hline $\begin{array}{c}\text { Karşılaş- } \\
\text { tırıcı }\end{array}$ & Tablo & - & 1 & - & - & 1 & 2 & 4 \\
\hline Nedensel & Tablo & 1 & - & - & 1 & - & - & 2 \\
\hline Döngüsel & Çember & - & 1 & 1 & - & - & 2 & 4 \\
\hline \multicolumn{2}{|c|}{ Toplam } & 10 & 7 & 8 & 12 & 2 & 7 & 46 \\
\hline
\end{tabular}

Tablo 7 incelendiğinde tüm Fen Bilimleri ders kitaplarında kullanılan grafik düzenleyicilerinden içeriksel ve biçimsel tür bakımından en fazla kullanılanların hiyerarşik-merkezcil ile sıralayıcı-zincir türlerinin olduğu görülmektedir. 5., 6., 7. ve 8. sınıf Fen Bilimleri ders kitaplarında yer alan grafik düzenleyicilerin sayıları açısından, sınıflar arasında çok büyük farklılıklar bulunmamaktadır. Sadece 2013 yılı programına göre hazırlanmış ve 2016-2017 Eğitim-Öğretim yılında okutulan 8. sınıf Fen Bilimleri ders kitabında, diğer tüm kitaplara göre daha az grafik düzenleyici yer aldı̆̆ belirlenmiştir. 
Tablo 8

5., 6., 7. ve ,8. Sinıf Fen Bilimleri Ders Kitaplarında Kullanılan Grafik Düzenleyicilerin Kullanım Amaçlarının Karşılaştırılmasına İlişkin Bulgular

\begin{tabular}{|c|c|c|c|c|c|c|c|}
\hline \multirow[b]{2}{*}{ Kullanım amacı } & \multicolumn{6}{|c|}{ Sınıf Düzeyi } & \multirow[b]{2}{*}{$\begin{array}{l}\text { Toplam } \\
\text { G.D. }^{* * *} \\
\text { Say1s1 }\end{array}$} \\
\hline & $\begin{array}{c}5 \\
2013^{*}\end{array}$ & $\begin{array}{c}5 \\
2017^{*}\end{array}$ & 6 & 7 & $\begin{array}{c}8 \\
\mathrm{GY}^{* *}\end{array}$ & $\begin{array}{c}8 \\
\mathrm{BY}^{* *}\end{array}$ & \\
\hline Sinıflama & 1 & 1 & 1 & - & - & - & 3 \\
\hline Değerlen-dirme & 3 & 2 & 2 & 1 & - & - & 8 \\
\hline Pekiştirme & 3 & 1 & 1 & 6 & - & 2 & 13 \\
\hline $\begin{array}{l}\text { Görsel Ön } \\
\text { Düzenleyici }\end{array}$ & 2 & - & - & - & - & - & 2 \\
\hline $\begin{array}{l}\text { Siralamayı } \\
\text { Gösterme }\end{array}$ & 1 & - & - & - & - & - & 1 \\
\hline Özetleme & - & 1 & 3 & 4 & 2 & 3 & 13 \\
\hline $\begin{array}{l}\text { Benzerlik ve } \\
\text { Farkl11ıkları } \\
\text { Gösterme }\end{array}$ & - & 1 & - & - & 1 & 1 & 3 \\
\hline Etkinlik & - & 1 & 1 & - & - & - & 2 \\
\hline Süreci Gösterme & - & - & - & 1 & - & - & $\begin{array}{c}1 \\
46\end{array}$ \\
\hline
\end{tabular}

Tablo 8 incelendiğinde 5., 6., 7. ve 8. sinıf Fen Bilimleri ders kitaplarında kullanılan grafik düzenleyicilerin sinıflandırma, değerlendirme, pekiştirme, görsel ön düzenleyici, sıralamayı gösterme, özetleme, benzerlik ve farklılıkları gösterme, etkinlik, süreci gösterme amaçlarında kullanıldığı görülmektedir. En fazla kullanım amacının "pekiştirme" ve "özetleme" olduğu, bunu "değerlendirme" amacının izlediği görülmektedir.

5. sınıf Fen Bilimleri ders kitabında grafik düzenleyicilerin daha çok sınıflandırma, değerlendirme, pekiştirme, görsel ön düzenleyici ve sıralamayı gösterme amaçlı kullanıldığı ve kullanım amaçlarının daha fazla çeşitlendiği görülürken, 8. sınıf kitaplarında özetleme amaçlı kullanımın daha fazla olduğu görülmektedir. İki farklı programa göre yazılan 5. sınıf kitapları kıyaslandığında, 2017 yılı programına göre yazılan kitapta grafik düzenleyici kullanım amacının daha fazla çeşitlendiği görülür.

Kitaplarda yer alan grafik düzenleyici çeşitlerinin neler olduğu ve dağılımlarının nasıl olduğunun belirlenmesi amacıyla grafik düzenleyici çeşitleri açısından düzenlenen verilere ait bulgular Tablo 9'da sunulmuştur. 
Tablo 9

5., 6., 7., ve 8 Sinıf Fen Bilimleri Ders Kitaplarında Kullanılan Grafik Düzenleyici

Türlerinin Sayısal Dă̆glımına İlişkin Bulgular

\begin{tabular}{|c|c|c|c|c|c|c|c|}
\hline \multirow{3}{*}{ Kullanım amacı } & \multicolumn{6}{|c|}{ Sınıf Düzeyi } & \multirow{3}{*}{$\begin{array}{c}\text { Toplam } \\
\text { G.D. }{ }^{* * *} \text { Sayıs }\end{array}$} \\
\hline & 5 & 5 & 6 & 7 & 8 & 8 & \\
\hline & $2013^{*}$ & $2017^{*}$ & & & $G Y^{* *}$ & $B Y^{* *}$ & \\
\hline Kavram A $\breve{g}_{1}$ & 1 & - & 1 & 1 & - & - & 3 \\
\hline Kavram Haritası & 2 & - & - & 4 & - & - & 6 \\
\hline Akış Diyagramı & 3 & - & - & - & - & - & 3 \\
\hline Minyatür Resim & 2 & 1 & - & - & - & - & 3 \\
\hline Anlam Çöz. Tab & 1 & 3 & 2 & - & - & 1 & 7 \\
\hline Neden-Sonuç & 1 & - & - & - & - & - & 1 \\
\hline Bağlantı Ağacı & - & 1 & - & 2 & - & - & 3 \\
\hline $\begin{array}{c}\text { Kiyaslama- } \\
\text { Zitlık }\end{array}$ & - & 1 & - & 1 & 1 & 1 & 4 \\
\hline Halka & 1 & 1 & - & - & - & 1 & 3 \\
\hline Olay Zinciri & - & - & 4 & 3 & 1 & 2 & 10 \\
\hline Venn Şeması & - & - & 1 & - & - & - & 1 \\
\hline Süreklilik Ö. & - & - & - & 1 & - & - & 1 \\
\hline Zihin Haritası & - & - & - & - & - & 1 & 1 \\
\hline Toplam & 11 & 7 & 8 & 12 & 2 & 6 & 46 \\
\hline
\end{tabular}

Tablo 9 incelendiğinde en fazla çeşitlemenin 7 farklı grafik düzenleyici çeşidi ile 2013 yılı programına göre yazılan 5. sınıf kitabında olduğu görülür. Bütün kitaplar düzeyinde en fazla yer alan grafik düzenleyici çeşidinin $10 \mathrm{kez}$ kullanılan olay zinciri ile 7 kez kullanılan anlam çözümleme tablosu olduğu, kitapların tümü için sadece $1 \mathrm{kez}$ kullanılanların da neden-sonuç diyagramı, venn şeması, süreklilik ölçeği ve zihin haritası olduğu görülmektedir.

\section{Tartışma ve Sonuç}

Bu çalışmada, Millî Eğitim Bakanlığı Talim Terbiye Kurulu tarafından 2013 yılı Fen Bilimleri Dersi Öğretim Programına göre hazırlanan 5-8. sınıf ders kitapları ile 2017 yılı Fen Bilimleri Dersi Öğretim Programına göre hazırlanan 5. sınıf ders kitabının grafik düzenleyicilerin kullanımı açısından analizi yapılmıştır. Her ne kadar bütün kitaplarda grafik düzenleyicilerin yer aldığı belirlenmişse de, bu sayının çok yeterli olduğu söylenemez. Kullanım amaçları incelendiğinde, çoğunlukla konuyu özetlemek, pekiştirmek ve değerlendirme amaçlı kullanıldıkları görülmektedir. Alanyazında grafik düzenleyicilerin konu ile ilgili özet ya da sonuç çıkarmada kullanılabileği gibi, bunun yanı sıra konunun kavramları arasında mevcut ilişkileri göstermede ve konu içindeki çeşitli fikirlerin düzenlenmesinde de etkili oldukları belirtilmiştir. Bunlara ek olarak, grafik düzenleyicilerin yeni öğrenilen bilgi ile önceki bilgilerin ilişkilendirilmesine de 
yardımcı olarak bilginin uzun dönemli hafizaya depolanıp daha sonra hatırlanmasına da yardımcı olmaktadır (Güzel-Özmen, 2009). Bu noktada kitaplarda yer alan grafik düzenleyicilerin burada bahsedilen özet ve sonuç çıkarma gibi benzer amaçlarla kullanıldığı görülmektedir. Diğer taraftan grafik düzenleyicilerin özellikle konuların öğretimi sırasında kullanılması ve öğrencinin konuyu öğrenmesine katkı sağlayacağ1 göz önüne alındığında, öğretim materyali olarak kitaplarda yer alan grafik düzenleyici sayısının yeterli olmadığı söylenebilir. Nakiboğlu ve Çamurcu (2013) tarafından Ortaöğretim Fizik ders kitaplarına yönelik yapılan çalışma sonuçları incelendiğinde, bu çalışmada da benzer sonuçlara ulaşıldığ 1 görülür. Fizik ders kitaplarının farklı sınıf düzeyleri için grafik düzenleyici kullanımı açısından önemli bir farklılık göstermediği ve kitaplarda kullanılan grafik düzenleyici sayısının da yeterli olmadığı sonucuna ulaşılmıştır.

Zaini, Mokhtar ve Nawawi (2010), yazılı materyalin veya öğrenciye güç gelen kavramların grafiksel materyal şeklinde ifade edildiğinde öğrencilerin konuya ait kavramlarını anlamak için kendilerine özgü yollar geliştirebildiklerini belirtmişlerdir. Ayrıca çalışmaların grafik düzenleyici kullanımının öğrencilerin anlama, performans ve öğrenme motivasyonunun iyileştirilmesinde etkisi olduğunu ortaya koyduğunu da ifade etmişlerdir. Zaini, Mokhtar ve Nawawi (2010), yaptıkları alanyazın taraması sonucunda, incelenen çalışmalarda grafik düzenleyici kullanımıyla anlamlı öğrenmenin desteklendiği yönünde sonuçlara ulaşmışlardır. Ausubel anlamlı sözel öğrenme kuramında, öğrencinin var olan bilgi birikiminin öğrenmeyi etkileyen en önemli unsurların başında geldiğini belirtmiştir. Bu kurama göre öğretilecek kavram, bilgi, teori ve ilkeler daha önce edinilen bilgilerle bağlantı kurulduğunda anlam kazanır. Bu durum grafik düzenleyici amaçları ile örtüştüğünden, anlamlı öğrenme için grafik düzenleyicilerin kullanımı çok önemlidir.

Çalışmada ulaşılan diğer bir sonuç da, kitaplarda en fazla kullanılan grafik düzenleyicilerden birinin anlam çözümleme tablosu olduğu ve özellikle 5. sınıf kitaplarında daha fazla yer aldı̆̆ 1 şeklindedir. Anlam çözümleme tablosu Anders ve Bos (1986) tarafından 3 farklı çalışmada kullanılmış ve hepsinde uygulama grubunda yer alan öğrencilerin kontrol grubuna göre daha başarılı olduğu sonucuna ulaşılmıştır. Anders ve Bos (1986), anlam çözümleme tablosu stratejisinin kuramsal temelinin Şema Teorisine dayandığını ve bilgi hipotezi ile de yakından ilişkili olduğu belirtmişlerdir. Bu teoriler, bilginin hiyerarşik olarak düzenlendiğini ve öğrencilere önceki bilgi ve yeni kavramlar arasındaki ilişkiyi öğretmenin, öğrencilerin bu yeni kavramları öğrenmelerine ve bilişsel yapılarına dahil etmelerine yardımcı olacağını önermektedir. Anlam çözümleme tablosunun bu teorilerle uyumu Anders ve Bos (1986) tarafindan şu şekilde açıklanmıştır: Anlam çözümleme tablosu ilk olarak öğrencilerin anlamsal ilişkileri veya sözcüklerin hiyerarşik organizasyonunu anlamalarına yardımcı olur. Böylece öğrenciler fikirlerin arasında ilişki oluşturabilir ve okuduklarını daha derinden anlayabilirler. İkinci olarak anlam çözümleme tablosu, öğrencilerin ön bilgilerini harekete geçirir. Tartışma sırasında, öğrenciler tartışılan terimler ve kavramlarla ilgili kişisel deneyimlerini ilişkilendirmeye teşvik edilir. Ön bilginin aktif hale getirilmesi ve ilişkilendirilmesi süreci öğrenmeye katkıda bulunur. Bu açıdan bakıldığında analiz edilen Fen Bilimleri ders kitaplarında anlam çözümleme tablosuna yer verilmesi, öğrencilerin öğrenmesine katkı sağlaması açısından oldukça önemlidir. Diğer taraftan kitaplarda yer alan anlam çözümleme tablosu sayısının çok fazla olduğu söylenemez. 
Kitaplarda en fazla yer alan grafik düzenleyicinin olay zinciri olduğu belirlenmiştir. Bu tür grafik düzenleyiciler olay ve sürecin düzenlenmesini göstermek amacıyla kullanılırlar. Konuyu özetlemek için oldukça uygun materyaller olmalarına karşın, anlamlı öğrenme için çok fazla etkiye sahip değillerdir. Diğer taraftan, öğretilen konunun kavramları arasındaki ilişkileri kurma, önbilgiler ile yeni konuyu bağlayacak ilişskilerin kurulmasını sağlama ve neden-sonuç ilişkileri kurarak bilgileri öğrencilerin zihinlerinde daha iyi yapılandırmalarına yardımcı olacak kavram haritası, neden-sonuç diyagramları ve kıyaslama-zitlık matrisleri türündeki grafik düzenleyicilerin kitaplarda çok fazla kullanılmadığı ulaşılan diğer bir sonuçtur. Özellikle dersin her aşamasında öğretim amaçlı kullanılabilmesinin yanısıra, öğrenenlerin mevcut bilişsel yapısında yer alan konuya yönelik kavramlar arasındaki ilişkileri ortaya çıkartılmasına da yardımcı olan kavram haritalarının (Nakiboğlu \& Ertem, 2010), sadece 5. ve 7. sınıf kitaplarında kullanıldığı, diğer kitaplarda kullanılmadığı belirlenmiştir.

\section{Öneriler}

Griffin ve Tulbert (1995), açıklayıcı bir ders kitabında sunulan bilgilerin anlaşılması ve hatırlanmasının okuyanlar için zorlayıcı olabileceğini çünkü, bunların zor kelimeler, karmaşık kavramlar ve ilkeler, alışılmamış tipografik özellikler, kendine özgü organizasyon yapıları ve birçok tablo ve resimler içerebildiği ve okuyucunun metni anlayabilmesi için tüm bu bilgileri bütünleştirmesi gerekeceğini ifade etmişlerdir. Bu açıdan bakıldığında ders kitaplarına uygun şekilde hazırlanmış grafiksel materyallerin eklenmesi, öğrencilerin bilgileri daha kolay ilişkilendirmesi ve kitaptaki açıklamaları daha iyi anlamlandırmasına katkı sağlayabilir. Ayrıca Griffin ve Tulbert (1995), kitaplarda kavramların birbiri ardına sunulmasının yoğun bir bilginin anlamayı zayıflatabileceğini belirtmektedirler. Bu nedenle yoğun bilgi sunmak yerine bu bilgiyi özetleyen grafiksel materyaller kullanmak öğrencinin öğrenmesini olumlu yönde etkileyebilir. Özellikle ilköğretimde öğrencilerin yaşlarının küçüklüğü nedeniyle uzun metinler sırasında dikkatleri kolayca dağılabilmekte ve öğrenciler sıkılabilmektedirler. Bunun önüne geçmede grafiksel materyaller son derece kullanışlı yardımcı öğretim metaryalleri olabilirler.

Bacanak, Karamustafaoğlu, Değirmenci ve Karamustafaoğlu (2011), İlköğretim Fen Bilimleri dersinin öğrencilerin anlamada en çok zorlandıkları derslerden biri olduğunu ifade etmişlerdir. Yazarlar, Fen Bilimleri ders kitaplarında konulara yönelik etkinlikler, deneyler öğrencilerin fazla sayıda duyu organına hitap edebildiğinde öğrenmenin o derece kalıcı olacağı ve konu içinde yer alan kavramlar ve ilişkilerinin unutulmasını zorlaştıracağını belirtmişlerdir. Grafik düzenleyiciler, öğrencilerin birden fazla duyu organına hitap etmesi ve aynı zamanda üst düzey düşünme becerilerinin gelişimini de sağlaması nedeniyle fen kavramlarının öğreniminde öğrencilere yardımcı olabilecektir. $\mathrm{Bu}$ nedenle kitaplarda hem sayısal olarak hem de farklı türlerde daha fazla grafik düzenleyici kullanımı önerilebilir.

Nakiboğlu ve Çamurcu (2014) tarafindan da belirtildiği gibi, ders kitaplarında sadece doğru şekilde hazırlanmış grafik düzenleyicilere yer verilmesi ile anlamlı öğrenmenin sağlanması veya bilginin kalıcı olması sağlanmayabilir. Bu nedenle de grafik düzenleyicileri doğru şekilde kullanacak öğretmenlerin de olması gerekir. Bu noktada meslekteki öğretmenler için grafik düzenleyicilere yönelik hizmet içi eğitim kursları ve çalıştayların düzenlenmesi önerilebilir. Bu çalıştaylarda özellikle işlik 
çalışmaları yaptırılarak öğretmenlerin materyalleri hazırlamaları ve bunları derslerde nasıl kullanabileceklerinin öğretilmesi önemlidir. Öğretmen adaylarına da eğitimleri sırasında grafik düzenleyicilere yönelik dersler verilebileceği gibi, özel öğretim yöntemleri çerçevesinde de grafik düzenleyiciler incelettirilebilir. $\mathrm{Bu}$ derslerde öğretmen adaylarına grafik düzenleyicileri, türlerini ve nasıl hazırlanacağını öğretmenin yanında ders kitaplarında yer alan grafik düzenleyicileri belirlemeleri ve bunların derslerde nasıl kullanılacağ1 da öğretilmelidir. Ayrıca ilköğretim öğrencilerinin yaşlarının küçük olması nedeniyle, kitaplarda yer alan grafik düzenleyicilerin kullanımı konusunda kendilerine yardımcı olunarak daha fazla yarar sağlanması mümkün olabilecektir. 


\section{Summary}

Graphic organizers are teaching and learning tools that present the relationship between concepts in a visual format. The inclusion of graphical organizers in the textbooks helps the learners to learn the theoretical knowledge presented in the book in a meaningful way while helping to connect the concepts of the subject and previous topics. When the literature concerning types of graphic organizers is examined, it is seen that there is a variety of and contextual and figural type of graphic organizers. The type of the graphic organizer varies depending on the content and purpose of teaching. This is why graphic organizers are classified differently by various researchers. Because of a large number of graphic organizers, the studies focus on the effect of teaching using a single graphic organizer rather than focus on examining the entire effect of graphic organizers on teaching. In the majority of these studies, it has been determined that graphic organizers have positive effects on learning.

Since one of the most challenging courses of secondary school is science course, it is important to use graphic organizers in the secondary school science teaching. Many researchers have pointed out that textbooks play an important role in science teaching and that textbooks are used both as a primary source outside the classroom and outside the classroom. The inclusion of graphical organizers in the science textbooks helps the students to learn the theoretical knowledge presented in the book in a meaningful way while helping to connect the concepts of the subject and previous topics. On the other hand, textbooks are prepared in the direction of curriculums, leading to many topics from the planning of the lesson to carrying out of the class activities. If the graphic organizers are placed in the textbooks appropriately, they also could help teachers see how the graphic organizers are used during teaching period.

Purpose and Significance: In this study, it was aimed to determine the degree and purpose of graphic organizers in secondary school science books and what type of graphic organizers they are. In the study three research questions were asked:

1. What types of graphic organizers are placed in secondary school science textbooks?

2. How is the distribution of graphic organizers according to units in secondary school science textbooks?

3. What are the differences and similarities in the distribution of graphic organizers according to classes in the textbooks of Secondary School Science?

Methods: This study is a qualitative research aimed at examining the use of graphic organizer and descriptive research model is used. The descriptive method describes an existing situation (Büyüköztürk, Kılıç Çakmak, Akgün, Karadeniz \& Demirel, 2009). The document analysis method was used for collecting data. A concept map which contains a classification of graphic organizers was used to analyses the textbooks. The textbooks of 5th, 6th, 7th and 8th-grade science, certificated by the Board of Education and Training, which are being studied in the academic year of 2017-2018 were analyzed and the results were compared in this study. To obtain inter-judge reliability of the analysis, all textbooks in the sample were analyzed by the two authors of the study. The differences are discussed by the authors, the corrections were provided and the analyses reached their final forms. 
Results: The findings of the comparison of 5th, 6th, 7th and 8th-grade science textbooks concerning the distribution of graphic organizers according to their sub-categories have been presented in Table 1 .

Table1

Findings on Numerical Distribution of Contextual and Figural Types of Graphic Organizers Used in 5th, 6th, th., and 8th Grades Science Textbooks.

\begin{tabular}{|c|c|c|c|c|c|c|c|c|}
\hline & \multicolumn{8}{|c|}{ Grade Level } \\
\hline Contextual & Figural & 5 & 5 & 6 & 7 & 8 & 8 & Sum \\
\hline Type & Type & $2013^{*}$ & $2017^{*}$ & & & $\mathrm{LY}^{* *}$ & $\mathrm{TY}^{* *}$ & of $\mathrm{GO}$ \\
\hline Hierar-chic & $\begin{array}{l}\text { Centri- } \\
\text { petal }\end{array}$ & 3 & 1 & - & 6 & - & - & 10 \\
\hline Sequence & Chain & 3 & - & 4 & 5 & 1 & 2 & 15 \\
\hline & Table & 3 & 4 & 2 & - & - & - & 9 \\
\hline Detailed & $\begin{array}{c}\text { Centri- } \\
\text { petal }\end{array}$ & - & - & 1 & - & - & 1 & 2 \\
\hline Compari-son & Table & - & 1 & - & - & 1 & 2 & 4 \\
\hline Causal & Table & 1 & - & - & 1 & - & - & 2 \\
\hline Circular & Circle & - & 1 & 1 & - & - & 2 & 4 \\
\hline \multicolumn{2}{|c|}{ TOTAL } & 10 & 7 & 8 & 12 & 2 & 7 & 46 \\
\hline
\end{tabular}

It was seen that from Table 1 that total 46 graphic organizers, 10 in the 5 th grade textbook (year 2013 curriculum), 7 in the 5th grade textbook (year 2017 curriculum), 8 in the 6th grade textbook, 12 in the 7th grade textbook and 2 in the 8th grade textbook (used in last year), and 7 in the 8th grade textbook (used in this year) were placed in the secondary school science textbooks analysed. When Table 1 is examined, it can be seen that the graphical organizers used in all Science textbooks are hierarchical-centric and sequential-chain types most used in terms of contextual and figural types. There is not a big numerical difference between the grades according to the graphic organizer's usage in the sciences textbooks.

Discussion and Conclusions: In this study, it was concluded that the graphic organizers were placed in all of the textbooks. It was found that the most of them were used for evaluation, enhancement, and summarization of the topic. It can be said that both the number of these graphic organizers and diversity of them in the textbooks are not satisfactory.

Since the graphic organizers can provide learning of complex and problematic topics easily, to use these materials in both lessons and textbooks are important. For this reason, it can be recommended to increase the number of graphic organizers in the science textbooks. 


\section{Kaynakça}

Amin, A. B. M. (2004). Using graphic organizers. ITE Teachers' Conference, 1 October, Institute of Technical Education, Singapore.

Anders, P. L., \& Bos, C. S. (1986). Semantic feature analysis: An interactive strategy for vocabulary development and text comprehension. Journal of Reading, 29(7), 610-616.

Ausubel, D. P. (1960). The use of advance organizers in the learning and learning and retention of meaningful verbal material. Journal of Educational Psychology, 51(5), 267-272.

Bacanak, A., Karamustafaoğlu, S., Değirmenci, S., \& Karamustafaoğlu, O. (2011). Fen öğretiminde bilgi haritası kullanımı: Ekosistem örneği. Dicle Üniversitesi Ziya Gökalp Eğitim Fakültesi Dergisi, 17, 133-145.

Başlantı, U. (2000, Eylül). Bilimsel okur-yazarlık ilkeleri açısından fen bilgisi derskitapları içerik analizi. IV. Fen Bilimleri Eğitimi Kongresi, Ankara.

Büyüköztürk, Ş., Kılıç Çakmak, E., Akgün, Ö. E., Karadeniz, Ş., \& Demirel, F. (2009). Bilimsel araştırma yöntemleri (3. Bask1). Ankara: Pegem A Akademi.

Dye, G. A. (2002). Graphic Organizers to the rescue! helping students link-and remember-information. Teaching Exceptional Children, 32(3), 72-76. https://doi.org/10.1177/004005990003200311.

Dönmez, C., Yazıc1, K., \& Sabanc1, O. (2007). Sosyal bilgiler derslerinde grafik düzenleyicilerin kullanımının öğrencilerin akademik bilgiyi elde etmelerine etkisi. Türk Ë̆itim Bilimleri Dergisi, 5(3), 437-459.

Ellis, E. (2004). Q\&A: What's the big deal with graphic organizers? (www.GraphicOrganizers.com) 05.11.2018 tarihinde https://tr.scribd.com/document/140226323/Q-and-a-About-Graphic-Organizers adresinden alınmıştır.

Griffin, C. C., Malone, L. D., \& Kameenui, E. J. (1995). Effects of graphic organizer instruction on fifth-grade students. The Journal of Educational Research, 89, 98107.

Griffin, C. C., \& Tulbert, B.L. (1995) The effect of graphic organizers on students' comprehension and recall of expository text: A review of the research and implications for practice. Reading \& Writing Quarterly: Overcoming Learning Difficulties, 11(1), 73-89. doi: 10.1080/1057356950110106.

Strangman, N., Vue, G., Hall, T., \& Meyer, A. (2003). Graphic organizers and implications for universal design for learning. Wakefield, MA: National Center on Accessing the General Curriculum. (Links updated 2014). Retrieved [insert date] from http://aem.cast.org/about/publications/2003/ncac-graphic-organizers-udl.html

Hudson P., Lignugaris-Kraft, B., \& Miller, T. (1993). Using content enhancements to 1mprove the performance of adolescents with learning disabilities in content classes. Learning Disabilities Research and Practice, 8(2), 106-127.

Karasar, N. (2005). Bilimsel araştırma yöntemi (8. Baskı). Ankara: Nobel Yayın Dağglım. 
Köseoğlu, F., Atasoy, B., Kavak, N., Budak, E., Tümay, H., Kadayıfçı, H. \& Taşdelen, U. (2003). Yapılandırmacı ögrenme ortamı için bir fen ders kitabı nasıl olmalıdır? (1. Baskı) Ankara: Asil Yayın Dağıtım.

Meyer, D. J. (1995). The effects of graphic organizers on the creative writing of third grade students. Kean College of New Jersey Reports. ED 380803

Morgil, İ., \& Yılmaz, A. (1999). Lise X. sınıf, kimya II ders kitaplarının öğretmen ve öğrenci görüşleri açısından değerlendirilmesi. Balıkesir Üniversitesi Fen Bilimleri Enstitüsü Dergisi, 1(1), 26-41.

Nakiboğlu, C. (2006). Fen ve teknoloji öğretiminde yanlış kavramalar (1. Bask1). In M. Bahar (Ed.), Fen ve Teknoloji Öğretimi (191-217). Ankara: Pegem A Yayıncılık.

Nakiboğlu C. (2003). Instructional misconceptions of Turkish prospective chemistry teachers about atomic orbitals and hybridization. Chemistry Education Research and Pracice, 4, 171-188.

Nakiboğlu, C., \& Ertem, H. (2010). Atom ile ilgili kavram haritalarının yapısal, ilişkisel ve öneri doğruluğu puanlaması analiz sonuçlarının kıyaslanması. Türk Fen Eğitimi Dergisi, 7(3), 60-77.

Nakiboğlu, C., \& Çamurcu, M. (2014). Grafik düzenleyiciler ve ortaöğretim fizik ders kitaplarinda kullanimlarinin incelenmesi. Abant İzzet Baysal Üniviversitesi Eğitim Fakültesi Dergisi, 14(1), 51-74.

Nakiboğlu, C., \& Kaşmer, N. (2017). Kimyasal değişim ünitesi ile ilgili karşılaştırmalı ön düzenleyici kullanımına yönelik öğrenci görüşlerinin incelenmesi. Türkiye Kimya Derneği Dergisi, Kısım C: Kimya Ĕ̆itimi, 2(1), 63-86.

Orak, S., Ermiş, F., Yeşilyurt, M. \& Keser, Ö.F. (2010). Kavram çarkı diyagramının öğrenme başarısına etkisi. Elektronik Sosyla Bilimler Dergisi, 9(31), 118-139.

Taber, K.S., Tsaparlis, G., \& Nakiboğlu, C. (2012). Student conceptions of ionic bonding: Patterns of thinking across three European contexts. International Journal of Science Education, 34(18), 2843-2873.

Tsaparlis G. (1997). Atomic orbitals, molecular orbitals and related concepts: conceptual difficulties among chemistry students. Research in Science Education, 27, 271-287.

Yener, D., \& Güzel, H. (2010). Kinematik konusuna ait problemlerin çözümüne grafik materyallerin etkisi. Selçuk Üniversitesi Ahmet Keleşoğlu Eğitim Fakültesi Dergisi, 30, 271-279.

Yıldırım, A., \& Şimşek, H. (2011). Sosyal Bilimlerde nitel araştırma yöntemleri (8.Bask1). Ankara: Seçkin Yayınevi.

Zaini, S.H., Mokhtar, S.Z., \& Nawawi, M. (2010). The effect of graphic organizer on students' learning in school. Malaysian Journal of Educational Technology, 10(1), 17-23. 